\title{
The Impact of Subsidized Microcredit Accessibility on Paddy Farms' Performance
}

\section{Iman Widhiyanto ${ }^{1 *}$, Nunung Nuryartono ${ }^{2}$ Harianto $^{2}$, Hermanto Siregar ${ }^{2}$}

${ }^{1}$ Agricultural Economics Doctoral Program, Bogor Agricultural University Indonesia

${ }^{2}$ Departments of Economic, Faculty of Economic and Management, Bogor Agricultural University Indonesia

Kampus IPB Dramaga, Jln. Raya Dramaga, Bogor Jawa Barat, 16680

*Corresponding Author: lslayangseta@gmail.com

Recieved: Desember 2017 | Revised: March 2018 | Accepted: March 2018

\begin{abstract}
Capital is required in farm to buy input such as fertilizer, pesticide, seed, land rent, labor wage, and to adopt the latest technology. To ease the burden of high loan interest and to increase the access of farm to formal credit, the government provides interest subsidy for Food Security and Energy Credit (Kredit Ketahanan Pangan dan Energi, KKP-E).This study was aimed to analyze the impact of accessing KKP-E on paddy farms' performance. The methods used in this study are descriptive analysis and propensity score matching model. Accessibility of KKP-E in research location was able to increase the fertilizer use of 7.43 percent per hectare, the pesticide use of 15.01 percent per hectare, the labor outside farm household use of 14.88 percent per hectare, the productivity of 3.33 percent per hectare, and the farm profit of 10.31 percent per hectare. The farm business scale in this study was categorized as small-scale business.
\end{abstract}

Keywords: Credit Accessibility; Farm's Performance; Interest Subsidy JEL Classification: H25; Q14; Q12

How to Cite: Widhiyanto, I., Nuryartono, N., Harianto, H., \& Siregar, H. (2018). The Impact of Microcredit Interest Subsidy Accessibility on Paddy Farms' Performance. Jurnal Ekonomi Pembangunan: Kajian Masalah Ekonomi dan Pembangunan, 19(1), 36-49. doi:https://doi. org/10.23917/jep.v19i1.5505

DOI: https://doi.org/10.23917/jep.v19i1.5505

\section{Introduction}

In the business world, both farm and nonfarm businesses, capitals are one of the essential production factors. A farm urgently needs capital to fulfill input production such as fertilizer, pesticide, seed, land rent, and labor wage. Besides the input production, it is also necessary for a farm to adopt the latest technology which is relatively expensive. The farm is able to use its own money and/or obtain it through loan/credit to meet the need of capital. The loan obtained is from both formal and informal financial institutions.
Microcredit is expected to meet the need of farm capital, particularly for smallholder farmers to further increase the production and productivity which eventually will increase farmer welfare.

There are many microcredit schemes, both formal and informal, provided by the government and private institution, yet, the access of smallholder farmer to credit is still limited. Limited access of farmer to microcredit is caused by many factors. One of the factors is the high-interest rate of commercial loan offered by the public bank. To ease the burden of high loan interest rate and to 
Jurnal Ekonomi Pembangunan: Kajian Masalah Ekonomi dan Pembangunan, 19 (1), 2018, 36-49

increase the farmer's accessibility to formal credit, the Government provides interest subsidy for Food Security and Energy Credit (Kredit Ketahanan Pangan dan Energi, KKP-E).Interest subsidy means that the Government bears a part of credit interest accessed by farm from the Executing Bank.

Dewi et al. (2015) conducted a study on the role of KKP-E in increasing the production and profit of rice farmers in the Kampar Regency of Riau. They employed Cobb-Douglas production function and multiple regressions methods to reach the study goals. The result of their study concluded that KKP-E of 46.98 percent was used for farm business, 29.43 percent for consumption, and 23.57 percent for other businesses. The used of KKP-E in the farm were intended for purchasing and providing inputs production. KKP-E had a role in increasing the rice production of 18.93 percent and significantly affected the farm profit. Dahri (2015) carried out the analysis of accessibility, economic impact, and the level of credit repayment of KKP-E program in the cattle farm in Central Java. He used logistic model and multiple regressions to reach the study goals. The study result showed that most cattle farmers used the KKP-E for cattle farm business, namely to buy feeder cattle or pregnant cattle, feed, medicine, and to repair the cage. Furthermore, KKP-E also positively affected the cattle population, farmer working hour, and business income of cattle farmer. Wati et al. (2014) conducted a research on the access and impact of microcredit on the production and income of organic rice farm in Bogor Regency. They employed Heckman Selection Model to reach their study goals. The result of their study indicated that microcredit led to a positive impact on the increasing production of organic rice, the quantity of input use, and labor. Finally, microcredit was able to increase the income of farm business despite it only obtained a relatively low.

In regard to the background described above, this study was aimed to investigate the impact of KKP-E interest subsidy accessibility on paddy farms' performance which included the use of fertilizer, pesticide, labor outside farm household, productivity, and farm profit. The novelties of this study are (1) the use of input production as an impact of KKP-E accessibility that rarely done by previous study and (2) the use of propensity score matching method to measure the impact of KKP-E accessibility.

\section{Research Methods}

The study was conducted in the Kendal Regency Province of Central Java. The Province of Central Java has selected due to the reason that the province is one of the largest paddy producers in Indonesia and also the province obtained the largest interest subsidy after East Java province. The study was performed from April to July 2017.

The type of data used in this research is crosssection data. Moreover, the data used in this study were primary and secondary data. Primary data were collected through questionnaire and direct interview with the sample respondents, both paddy farm which accessed and did not access the KKP-E. The questionnaire used consisted of the list and structured questions which were followed by interview for things that required clarification from the respondents. Primary data were also obtained from an interview with the Executing Bank officers who distributed the KKP-E in Kendal Regency. Secondary data were sourced from the Ministry of Finance, Executing Banks, Statistics of Indonesia, the Ministry of Agriculture, the Government of Kendal Regency, scientific journals, and document or publication from the related institution.

The number of a questionnaire distributed to the respondents amounted to 300 questionnaires with details of 200 questionnaires for treatment respondent (accessed KKP-E) and 100 questionnaires for control respondent (did not access KKP-E). After being collected, examined, and investigated, there were many questionnaires that were not filled and or filled yet were not able to be used since several data were considered not valid. The number of a questionnaire that was able to be used in this study amounted to 258 questionnaires which consisted of 175 treatment samples and 83 control samples. 
Avalaible online at http://journals.ums.ac.id, Permalink/DOI: 10.23917/jep.v19i1.5505

Jurnal Ekonomi Pembangunan: Kajian Masalah Ekonomi dan Pembangunan, 19 (1), 2018, 36-49

Table 1. Variables used in the probit model for propensity score

\begin{tabular}{|c|c|c|c|}
\hline Symbol & & Symbol definition & Data Explanation \\
\hline AKSS & : & Accessing KKP-E & Accessing KKP-E $=1$, Others $=0$ \\
\hline UMUR & : & Age & The age of respondent \\
\hline JLWP & : & Education duration & $\begin{array}{l}\text { Elementary }=6 \text {, Junior High School }=9 \text {, Senior High } \\
\text { School }=12 \text {, College }=16\end{array}$ \\
\hline PNUT & : & Farm income & Million rupiah \\
\hline LLHN & : & Width of cultivated area & Square meter \\
\hline AGUN & : & Collateral & Collateral ownership $=1$, Others $=0$ \\
\hline TBKR & : & Interest rate & Annual interest rate \\
\hline RNLK & : & Financial literacy index & Index range from $0-100$ \\
\hline $\mathrm{KLBH}$ & : & Farmer group legal status & Legal ownership $=1$, Others $=0$ \\
\hline JAKSB & : & Credit access experience & Frequently credit accessibility \\
\hline TOTPINJ & : & Loan amount & Amount disburse to farm \\
\hline POKA & : & Group Activeness & Active $=1$, Others $=0$ \\
\hline DTRT & : & Farm Location & Upland $=1$, Lowland $=0$ \\
\hline
\end{tabular}

Table 2. Outcome variables for farms' performance

\begin{tabular}{llll}
\hline \multicolumn{1}{c}{ Symbol } & \multicolumn{1}{c}{ Symbol definition } & \multicolumn{1}{c}{ Data Explanation } \\
\hline TPUP & $:$ & Fertilizer use & Kilogram/Hectare \\
TPEST & $:$ & Pesticide use & Unit measurement (CC/Sachet)/Hectare \\
TKLT & $:$ & Labor outside farm household use & Hours/Hectare \\
PDTV & $:$ & Productivity & Quintal/Hectar \\
LBUT & $:$ & Farm profit & Million Rupiah/Hectare \\
\hline
\end{tabular}

The model was used to measure the impact of KKP-E on paddy farms' performance is Propensity Score Matching (PSM). PSM is an alternative method to estimate the impact of a treatment on a certain subject. In PSM, observation is divided into two groups those are group given the treatment and group which does not receive the treatment, called as a control group. The treatment effect is defined as the impact of certain treatment variable on outcome or unit target. In general, the treatment effect is estimated through a counterfactual approach which is termed as counterfactual causality by scientists. The concept is based on the assumption that causality is a comparison between the outcome of a unit if the unit receives treatment through certain way and the outcome of the same unit if it does not receive treatment. If someone performs observation only on one unit with the status of receiving treatment, the status for a unit that does not receive treatment is called as a counterfactual status which means that the unit is not being observed (Cerulli 2015).

Rosenbaum and Rubin firstly introduced PSM model in 1983. PSM is applied to reduce bias in research. Comparison between two different conditions through linear regression model will lead to the potency of bias despite adjustment is made. The analysis using PSM is able to perform adjustment for covariate in two groups and may reduce bias better than the modeling technique in the conventional multivariate analysis. This approach performs matching through the propensity score from treatment group and control group. Propensity score becomes probability value when the subject is considered not receiving treatment, yet in fact, the subject receives treatment. Propensity score in this study was resulted by using probit/logit model. 
Avalaible online at http://journals.ums.ac.id, Permalink/DOI: 10.23917/jep.v19i1.5505

Jurnal Ekonomi Pembangunan: Kajian Masalah Ekonomi dan Pembangunan, 19 (1), 2018, 36-49

Table 3. Farm characteristics for cultivated area width, irrigation, land ownership

\begin{tabular}{|c|c|c|c|c|c|c|}
\hline \multirow[t]{2}{*}{ Characteristics of Respondent } & \multicolumn{2}{|c|}{$\begin{array}{l}\text { KKP-E } \\
(\mathrm{N}=175)\end{array}$} & \multicolumn{2}{|c|}{$\begin{array}{l}\text { Non-KKP-E } \\
(\mathrm{N}=83)\end{array}$} & \multicolumn{2}{|c|}{$\begin{array}{c}\text { Total Respondent } \\
\qquad(\mathrm{N}=\mathbf{2 5 8})\end{array}$} \\
\hline & Total & Percent & Total & Percent & Total & Percent \\
\hline \multicolumn{7}{|l|}{ Width Cultivated Area } \\
\hline$<=0.5 \mathrm{Ha}$ & 94 & $53.7 \%$ & 54 & $65.1 \%$ & 148 & $57.4 \%$ \\
\hline$>0.5-1 \mathrm{Ha}$ & 60 & $34.3 \%$ & 22 & $26.5 \%$ & 82 & $31.8 \%$ \\
\hline$>1-1.5 \mathrm{Ha}$ & 12 & $6.8 \%$ & 5 & $6 \%$ & 17 & $6.6 \%$ \\
\hline$>1.5-2 \mathrm{Ha}$ & 7 & $4 \%$ & 1 & $1.2 \%$ & 8 & $3.1 \%$ \\
\hline$>2 \mathrm{Ha}$ & 2 & $1.2 \%$ & 1 & $1.2 \%$ & 3 & $1.1 \%$ \\
\hline \multicolumn{7}{|l|}{ Irrigation } \\
\hline Modern & 67 & $38 \%$ & 23 & $28 \%$ & 90 & $35 \%$ \\
\hline Simple & 89 & $51 \%$ & 54 & $65 \%$ & 143 & $55 \%$ \\
\hline Rain fed & 19 & $11 \%$ & 6 & $7 \%$ & 25 & $10 \%$ \\
\hline \multicolumn{7}{|l|}{ Land Ownership } \\
\hline Own farm & 81 & $46 \%$ & 56 & $67 \%$ & 137 & $53 \%$ \\
\hline Own farm and Rent & 36 & $21 \%$ & 12 & $14 \%$ & 48 & $19 \%$ \\
\hline Rent & 58 & $33 \%$ & 15 & $18 \%$ & 73 & $28 \%$ \\
\hline
\end{tabular}

Table 4. Farm characteristics for fertilizer use, pesticide use, labor from outside farm household use

\begin{tabular}{lccc}
\hline \multicolumn{1}{c}{ Characteristics of Respondent } & $\begin{array}{c}\text { KKP-E } \\
(\mathbf{N = 1 7 5 )}\end{array}$ & $\begin{array}{c}\text { No n-K K P - E } \\
(\mathbf{N = 8 3 )}\end{array}$ & $\begin{array}{c}\text { Total Sample } \\
\text { (N=258) }\end{array}$ \\
\hline Fertilizer use & & & \\
\hline Maximum (Kg/Ha) & 1458.33 & 1416.67 & 1458.33 \\
Minimum (Kg/Ha) & 357.14 & 437.5 & 357.14 \\
Average (Kg/Ha) & 877.06 & 842.47 & 865.93 \\
Pesticide use & & & \\
Maximum (unit/Ha) & 40.6 & 30 & 3 \\
Minimum (unit/Ha) & 3 & 4 & 13.39 \\
Average (unit/Ha) & 13.79 & 12.56 & 1333.33 \\
The use of labor from farm household & & & 45 \\
\hline Maximum (hour/season/Ha) & 1080 & 1333.33 & 508.25 \\
Minimum (hour/season/Ha) & 45 & 102.86 & \\
Average (hour/season/Ha) & 507.84 & 509.09 & 945 \\
The use of labor outside farm household & & & 175 \\
Maximum (hour/season/Ha) & 945 & 784 & 561.68 \\
Minimum (hour/season/Ha) & 280 & 175 & \\
Average (hour/season/Ha) & 582.78 & 517.20 & \\
\hline & Source: Primary data, processed 2017 & \\
\hline
\end{tabular}

The variables used in the regression refer to economic theories and previous studies related to microcredit accessibility. Chauke and
Anim (2013) employed variables age, level of education attained, gender, extension service, market information, membership to cooperatives, 
production cost as predictors to credit availability. Ololade and Olagunju (2013) investigated the determinants of access to credit by rural farmers in Oyo State. The study revealed that gender, marital status, guarantor and high-interest rate are the main factors determining farmers' access to credit. Vitor and Abankwah (2012) stated that regional location, gender, engagement in other economic activities, level of agricultural commercialization, farmer years education influence demand for formal credit.

The probit/logit model used in this study is described in the equation (1).

$\begin{aligned} \text { AKSS }= & \beta_{0}+\beta_{1} \text { UMUR }+\beta_{2} \text { JLWP }+\beta_{3} \text { PNUT }+\beta_{4} \text { LLHN }+\beta_{5} \text { AGUN }+\beta_{6} \text { TBKR }+\beta_{7} \text { RNLK }+ \\ & \beta_{8} \text { KLBH }+\beta_{9} \text { JAKSB }+\beta_{10} \text { TOTPINJ }+\beta_{11} \text { POKA }+\beta_{12} \text { DTRT }+ \text { U.m. }\end{aligned}$

Notes:

$\beta_{0}=$ Intercept $($ Constanta)

$\beta_{1}-\beta_{12}=$ Coefficient regressioneach variable

$\mathrm{U}=$ Error term

Nkuah et al. (2013) stated that gender and age affect credit accessibility. Han (2008) and Pandula (2011) stated that education level is an important factor in accessing credit. Diagne and Zeller (2001) included asset variables, income, household size, while Messah and Wangai (2011) use income and the number of family dependents

After propensity score matching is done, the next step is to analyze the variables of farms' performance (outcome variables). Variables in equation (1) deployed as covariates for matching procedure in treatment effect analysis. In this analysis, the average value of farm performance variable from the treatment group and control group was compared. The average difference of outcome variable value is the average treatment effect on treated (ATET/ATT) which reflects the impact of accessing and using the KKP-E loan.

\section{Result and Discussion}

The number of farms selected as research sample was 258 which located in nine sub-districts and 13 villages in the region of Kendal Regency. The respondent joined 13 farmer groups which were a part of 3,909 members of farmer group. The research sample consisted of farms which accessed KKP-E amounted to 175 respondents $(\mathrm{N})$ and the group that did not access KKP-E of 83 respondents.

\subsection{Farm characteristics}

Farm characteristics explained the variables that attached to paddy farm in research location. Variables included in farm characteristics were width cultivated area, type of irrigation, land ownership, fertilizer use, pesticide use, labor from farm household use, labor outside farm household use, costs, production, farm income, and farm profit. The description of farm characteristics is presented in Table 3, 4, and 5 .

The width of cultivated land of farmer sample varied from 0.1 hectares to 3.5 hectares. The percentage of the farm which cultivated land less than 0.5 hectare was around 57.4 percent. Therefore, most samples were classified as peasant farms in which their farm business will not able to support their necessity/subsistence. Moreover, a farm that owned cultivated land for more than 2 hectares was only 1.1 percent. Irrigation plays an important role in rice farm, as it is known that rice plant consumes a large amount of water thus the sustainability of rice plant really depends on water. There are three systems of irrigation applied in research location, namely modern irrigation, simple irrigation, and rain-fed irrigation system. The highest percentage of respondents in which their cultivated land was irrigated through simple irrigation system was 55 percent. Cultivated land ownership was classified into three, namely own farm, own farm and rent, and rent. About 53 percent of respondents cultivated their own farm, 19 percent cultivated their own farm and rent another farm, and 18 percent of respondents cultivated farm by renting the land. 
Avalaible online at http://journals.ums.ac.id, Permalink/DOI: 10.23917/jep.v19i1.5505

Jurnal Ekonomi Pembangunan: Kajian Masalah Ekonomi dan Pembangunan, 19 (1), 2018, 36-49

Table 5. Characteristics of production, farm income, and farm profit

\begin{tabular}{|c|c|c|c|}
\hline Characteristics of Respondent & $\begin{array}{l}\text { KKP-E } \\
(\mathrm{N}=175)\end{array}$ & $\begin{array}{c}\text { Non-KKP-E } \\
(\mathrm{N}=83)\end{array}$ & $\begin{array}{l}\text { Total Sample } \\
\quad(\mathrm{N}=\mathbf{2 5 8})\end{array}$ \\
\hline \multicolumn{4}{|l|}{ Production } \\
\hline Maximum (quintal/Ha) & 83.3 & 68.5 & 83.3 \\
\hline Minimum (quintal/Ha) & 40 & 40 & 40 \\
\hline Total Sample (quintal/Ha) & 58.8 & 52 & 56.7 \\
\hline \multicolumn{4}{|l|}{ Farm income } \\
\hline Maximum (million rupiahs/Ha) & 30 & 24.3 & 30 \\
\hline Minimum (million rupiahs/Ha) & 12.5 & 12.5 & 12.5 \\
\hline Average (million rupiahs/Ha) & 20.75 & 17.6 & 19.7 \\
\hline \multicolumn{4}{|l|}{ Farm profit } \\
\hline Maximum (million rupiahs/Ha) & 20 & 14.8 & 20 \\
\hline Minimum (million rupiahs/Ha) & 3.8 & 4.2 & 3.8 \\
\hline Average (million rupiah/Ha) & 10.5 & 9 & 10 \\
\hline
\end{tabular}

Source: Primary data, processed 2017

Table 4 provides farm characteristics which included fertilizer use, pesticide use, the use of labor from household, and the use of labor outside farm household. The measurement unit of each variable was equated to the hectare. Based on the data Table 4, the use of chemical/artificial fertilizer in the group that accessed KKP-E on average was 877.06 kilogram per hectare. Moreover, in the group that did not access KKP-E, the average use was 865.93 kilogram per hectare. The use of pesticide in group accessed KKP-E on average was 13.79 unit of measurement per hectare. The group that did not access KKP-E used pesticide in an average of 12.56 unit of measurement per hectare. The use of labor from farm household in group accessed KKP-E in average was 507.84 hour per season per hectare, while the group that did not access KKP-E used labor from farm household in an average of 509.09 hours per season per hectare. The use of labor outside farm household in the group that accessed KKP-E on average was 582.78 hour per season per hectare. Moreover, the group that did not access KKP-E used labor outside farm household which amounted in average to 517.20 hours per season per hectare. Hence, it is said that the average use of fertilizer, pesticide, and labor outside farm household in the group that accessed KKP-E was higher compared to the group that did not access KKP-E. In addition, the use of labor from farm household was higher in the group that did not access KKP-E.

Table 5 provides farm characteristics which included production, farm income, and farm profit. The unit of measurement of each variable was equated to the hectare. The average rice production in the group that accessed KKP-E was 58.8 quintal per hectare, while it was 52 quintal per hectare in the group that did not access KKP-E. Along with the production, the group that accessed KKP-E generated better farm income than the group that did not access KKP-E. The average farm income of the group that accessed KKP-E was Rp20.75 million per hectare. The average farm income group that did not access KKP-E was Rp17.6 million per hectare. Farm profit followed farm income in which the group that accessed KKP-E gained higher farm profit than the group that did not access KKP-E. The average farm profit group that accessed KKP-E was Rp10.5 million per hectare, while the average farm profit group that did not access KKP-E was Rp9 million per hectare. 
Avalaible online at http://journals.ums.ac.id, Permalink/DOI: 10.23917/jep.v19i1.5505

Jurnal Ekonomi Pembangunan: Kajian Masalah Ekonomi dan Pembangunan, 19 (1), 2018, 36-49

Table 6. Characteristics of access to credit, amount of credit, interest rate

\begin{tabular}{|c|c|c|c|c|c|c|}
\hline \multirow[t]{2}{*}{ Characteristics of Respondent } & \multicolumn{2}{|c|}{$\begin{array}{l}\text { KKP-E } \\
(\mathrm{N}=175)\end{array}$} & \multicolumn{2}{|c|}{$\begin{array}{c}\text { Non-KKP-E } \\
(\mathrm{N}=83)\end{array}$} & \multicolumn{2}{|c|}{$\begin{array}{c}\text { Total Respondent } \\
(\mathrm{N}=\mathbf{2 5 8})\end{array}$} \\
\hline & Total & Percent & Total & Percent & Total & Percent \\
\hline \multicolumn{7}{|l|}{ Accessibility of credit } \\
\hline Access & 175 & $100 \%$ & 55 & $66.3 \%$ & 230 & $89.1 \%$ \\
\hline Do not have access & - & - & 28 & $33.7 \%$ & 28 & $10.9 \%$ \\
\hline \multicolumn{7}{|l|}{ The amount of credit received } \\
\hline Do not borrow & 0 & - & 28 & $33.7 \%$ & 28 & $10.9 \%$ \\
\hline$<$ Rp. 5 million & 49 & $28 \%$ & 20 & $24.2 \%$ & 69 & $26.7 \%$ \\
\hline Rp. 5 - 10 million & 70 & $40 \%$ & 6 & $7.2 \%$ & 76 & $29.4 \%$ \\
\hline Rp. 10 - 15 million & 27 & $15.4 \%$ & 14 & $16.8 \%$ & 41 & $15.9 \%$ \\
\hline$\geq$ Rp. 15 million & 29 & $16.6 \%$ & 15 & $18.1 \%$ & 44 & $17.1 \%$ \\
\hline \multicolumn{7}{|l|}{ The interest rate on credit } \\
\hline Do not borrow & - & - & 28 & $33.7 \%$ & 28 & $10.9 \%$ \\
\hline 0 percent & - & - & 7 & $8.4 \%$ & 7 & $2.7 \%$ \\
\hline$\leq 5.5$ percent & 175 & $100 \%$ & 11 & $13.2 \%$ & 186 & $72.1 \%$ \\
\hline $5.6-12$ percent & - & - & 6 & $7.2 \%$ & 6 & $2.3 \%$ \\
\hline $12-18$ percent & - & - & 12 & $14.6 \%$ & 12 & $4.6 \%$ \\
\hline$\geq 18$ percent & - & - & 19 & $22.9 \%$ & 19 & $7.4 \%$ \\
\hline
\end{tabular}

Table 7. The use of fertilizer, pesticide, labor outside farm household, production, land productivity, and farm profit

\begin{tabular}{lcccc}
\hline \multicolumn{1}{c}{ Name of Variable } & Mean & $\begin{array}{c}\text { Standard } \\
\text { Deviation }\end{array}$ & Min & Max \\
\hline Fertilizer use (kg) & 526.24 & 404.66 & 100 & 3400 \\
Non-KKP-E & 460.06 & 451.43 & 100 & 3400 \\
KKP-E & 557.62 & 377.82 & 100 & 2000 \\
Pesticide use (unit of use) & 6.84 & 4.75 & 2 & 35 \\
Non-KKP-E & 6.19 & 4.80 & 2 & 35 \\
KKP-E & 7.15 & 4.70 & 2 & 28 \\
The labor outside household use (hours) & 371.24 & 328.44 & 21 & 2100 \\
Non-KKP-E & 312.13 & 319.66 & 21 & 2100 \\
KKP-E & 399.28 & 329.72 & 42 & 1750 \\
Production (quintal) & 35.36 & 27.62 & 5 & 180 \\
Non-KKP-E & 29.08 & 26.85 & 5 & 180 \\
KKP-E & 38.34 & 27.56 & 6 & 150 \\
Land productivity (quintal/ha) & 56.69 & 10.14 & 40 & 83.33 \\
Non-KKP-E & 52.15 & 6.65 & 40 & 68.57 \\
KKP-E & 58.86 & 10.79 & 40 & 83.33 \\
Farm profit (million rupiah) & 6.14 & 5.03 & 0.85 & 30 \\
Non-KKP-E & 4.89 & 4.68 & 0.85 & 29.62 \\
KKP-E & 6.73 & 5.09 & 1 & 30 \\
\hline
\end{tabular}

Source: Primary data, processed 2017 


\subsection{Credit Characteristics}

Characteristics of credit described variables that attached to the credit distributed in research location which included accessibility of credit, the amount of credit received, and interest rate of credit. Characteristic of credit is depicted in Table 6.

About 89.1 percent of respondent accessed credit. The number of the respondent that accessed KKP-E was 175 people, while 55 respondents accessed credit Non-KKP-E. Furthermore, around 10.9 percent of respondent completely did not access the credit. The amount of credit received by farm both by accessing KKP-E and borrowing from financial institution varied with the maximum amount of Rp50 million. The number of the respondent that received loan less than Rp5 million was 26.7 percent, a respondent who borrowed between Rp5 million to Rp10 million was about 29.6 percent, a respondent who borrowed between Rp10 million to Rp15 million was approximately 15.9 percent, and respondent who borrowed more than Rp 15 million was around 17.1 percent. Interest rate of credit which was applicable to the loan varied from 0 to 24 percent per year. A respondent who borrowed KKP-E bore the same interest rate of 5.5 percent in any banks where they obtained the loan. The number of respondents that bore interest rate less or equaled to 5.5 percent per year was 72.1 percent, respondent who bore interest rate between 5.6 12 percent per year was 2.3 percent, respondent who bore interest rate of $12-18$ percent per year was 4.6 percent, and respondent who bore the interest rate equaled to or higher than 18 percent per year was 7.4 percent.

\subsection{The outcome of KKP-E interest subsidy accessibility}

Each policy applied by the Government should be directed to achieve the welfare of society. One of the policies in the agricultural sector that have been taken by the Government is the provision of KKP-E interest subsidy. The government expects that the farmers access to credit will increase through the provision of KKP-E interest subsidy, thus capital constraint faced by farmers will be solved. Related to the policy of credit interest subsidy program, several farm performances or outcomes were analyzed in this study, included (1) fertilizer use, (2) pesticide use, (3) labor outside farm household use, (4) land productivity, and (5) farm profit.

Fertilizer, chemical fertilizer, organic fertilizer, and manure, is an essential production input in rice farm business. The use of fertilizer less than the standard probably will decline the production. Similarly, excessive use of fertilizer will also result in an adverse impact on land fertility. Fertilizer should be used in accordance with the amount required by rice plant, yet fertilizer should also be applied at the right timing. Fertilizer used in this study was chemical fertilizer produced by fertilizer factories such as Urea, NPK Phonska, SP36, KCl, and ZA. The average amount of chemical fertilizer used in research location was 526.24 kilograms. For a farm that accessed KKP-E, the quantity of fertilizer for rice plant applied was higher compared to a farm that did not access KKP-E.

Besides fertilizer, the pesticide is also an important input in rice farm. The pesticide is a substance that regulates and stimulates the growth of other substance and microorganisms, or virus which is applied to protect the plant. There are various types of pesticide, thus its use is adjusted to plant diseases. There are five types of pesticide mostly applied in the farm of research location, namely Danke, DMA, Explore, Regent, and Matador. The use of those five types of pesticide was based on the size of sachet and bottle. The average use of pesticide per season in research location was 6.84 unit of measurement. Farm business that accessed KKP-E applied more pesticide than farm business that did not access KKP-E. By considering the cost structure, in average, farm business that accessed KKP-E spent Rp211 thousands to buy pesticide, while Non-KKP-E farm spent Rp181 thousand to buy pesticide. 
Avalaible online at http://journals.ums.ac.id, Permalink/DOI: 10.23917/jep.v19i1.5505

Jurnal Ekonomi Pembangunan: Kajian Masalah Ekonomi dan Pembangunan, 19 (1), 2018, 36-49

Table 8. Probit regression to obtain propensity score

\begin{tabular}{clcccc}
\hline No & \multicolumn{1}{c}{ Name of Variable } & Coefficient & $\mathbf{z}$ & $\mathbf{p}>\mathbf{z} \mid$ \\
\hline 1. & Age & -0.022 & -1.41 & 0.160 \\
2. & Education duration & -0.073 & -0.98 & 0.328 \\
3. & Farm income & -0.129 & -1.62 & 0.104 \\
4. & With of cultivated area & 0.001 & 1.72 & 0.086 & $*$ \\
5. & Collateral & 1.750 & 4.95 & 0.000 & $* * *$ \\
6. & Interest rate & -0.251 & -5.84 & 0.000 & $* * *$ \\
7. & Financial literacy index & 0.028 & 2.20 & 0.028 & $* *$ \\
8. & Farmer group legal status & 1.005 & 2.08 & 0.038 & $* *$ \\
9. & Credit accessibility experience & 0.952 & 6.79 & 0.000 & $* * *$ \\
10. & Loan amount & 0.048 & 1.78 & 0.075 & $*$ \\
11. & Group activeness & 0.737 & 1.84 & 0.066 & $*$ \\
12. & Farm location & 0.689 & 1.74 & 0.082 & $*$ \\
13. & Constanta & -3.037 & -1.56 & 0.113 & \\
\hline
\end{tabular}

Number Observation=258; $\mathrm{LR} \mathrm{Chi}^{2}(10)=186.80 ;$ Prob $>\mathrm{Chi}^{2}=0.0000$

Log likelihood=-68.663; Pseudo $\mathrm{R}^{2}=0.5763$

$* * *$ significant at $1 \% ; * *$ significant at $5 \%, *$ significant at $10 \%$

Table 9. Measuring the performance of KKP-E using psmatch2

\begin{tabular}{llccccc}
\hline \multirow{2}{*}{ Name of Outcome Variable } & Sample & KKP-E & $\begin{array}{c}\text { Non- } \\
\text { KKP-E }\end{array}$ & Difference & S.E & T-Stat \\
\hline \multirow{2}{*}{ Fertilizer use } & Unmatched & 877.06 & 842.47 & 34.58 & 22.58 & 1.53 \\
& ATT & 877.06 & 814.43 & 62.62 & 97.89 & 0.64 \\
Pesticide use & Unmatched & 11.99 & 10.39 & 1.60 & 0.33 & 4.83 \\
\multirow{2}{*}{ Labor outside farm household } & Unmatched & 582.78 & 517.20 & 65.58 & 17.55 & 3.74 \\
use & ATT & 582.78 & 505.81 & 76.97 & 69.76 & 1.10 \\
\multirow{2}{*}{ Productivity } & ATT & 59.88 & 52.15 & 7.73 & 1.11 & 6.97 \\
\multirow{2}{*}{ Farm profit } & ATT & 59.88 & 58.15 & 1.73 & 5.27 & 0.33 \\
& Unmatched & 10.66 & 9.02 & 1.64 & 0.37 & 4.41 \\
& ATT & 10.66 & 9.72 & 0.93 & 1.57 & 0.59 \\
\hline \multirow{2}{*}{ Unmatched = before matching } & & &
\end{tabular}

The agricultural sector, particularly food crop in Indonesia, still uses labor extensively. Farm business with a large number of family member tended to involve a family member in cultivating the farm. Moreover, farm business with a small number of a family member will hire labor outside the farm household. Labors outside farm household were paid according to their working hour. The longer the working hour used by labor outside farm household, the higher the cost should be spent by farm business. In this study, the average use of working hour of labor outside farm household by farm business was 371.24 hour. The farm that accessed KKP-E used more labor outside of farm household when compared to a farm that did not access KKP-E. 
The expected production output of rice farm is an abundant rice harvest. The more rice grains produced from the cultivated land, the more the quantity of rice harvested in quintal, thus farm income will further increase with an assumption of the stable price. In this study, rice production was measured in a unit of quintal. The average rice production in research location was 35.36 quintal. The farm that accessed KKP-E produced higher rice production than a farm that did not access KKP-E.

Productivity is the ability to produce output at the certain measurement of input. Higher land productivity results in the better farm business. Productivity can be increased by implementing the latest technology and improving the production input, both quantity, and quality. The average rice productivity in research location was 56.69 quintal per hectare. The farm that accessed KKP-E had higher productivity than a farm that did not access KKP-E.

Farm profit is the difference between the value of farm income and cost spent on production. Farm profit is the source of main income of the head of the family whose main occupation was a farmer. Higher farm profit leads to improvement of farmer welfare. In this research, farm profit was measured in a unit of one million rupiahs. The average farm profit in research site was Rp6.14 million. Farm business that accessed KKP-E gained higher farm profit compared with farm business that did not access KKP-E.

\subsection{Measuring the impact of KKP-E accessibility on-farm performance}

Impact expected to be created from the policy of KKP-E interest subsidy was measured by comparing the performance of two groups, namely treatment group, and control group. In measuring the impact of treatment, PSM method was applied to avoid bias. Matching the propensity score is a popular approach to assessing the impact of a treatment. There are three syntaxes provided in Stata to perform estimation using PSM, namely (1) teffectpsmatch, (2) psmatch2, and (3) pscore (Cerulli, 2015). In this study, the first two syntaxes were applied and the result was compared.

\section{Measuring the impact using psmatch2.}

The first step was to determine the propensity score of treatment group and control group by performing probit regression on covariate variables. The result of probit regression to determine propensity score can be seen in Table 8 . There were 10 variables used in the matching process. Variables that significantly affected the accessibility of KKP-E at the level of 1 percent, 5 percent, and 10 percent were the width of the cultivated area, collateral, credit interest rate, financial literacy index, farmer group legal status, credit accessibility experience, loan amount, group activeness, and farm location. In addition, variables that did not significantly affect the accessibility of KKP-E included age, education duration, and farm income.

Farm performance was calculated using PSM through the method of the nearest neighbor matching with no replacement by matching the closest propensity score of each group in one matching. This matching will produce a value of average treatment effect on treated (ATT) which is the difference between treatment group and control group.

The insignificant variables affecting the KKP-E accessibility of age, sex, and farm income are expended as covariates in calculating average treatment effects (ATT). Thus, the variables used as covariates in calculating impacts include land area, collateral, interest rate, financial literacy index, farmer group legal status, access to credit experience, loan value, group activeness, and farm location. The output used is all modified in units of a hectare. The result performance should be done balancing test to determine the existence of bias. Based on balancing test, then the location of farming variables are removed from covariate, so the new output generated can be seen in table 9. 
Avalaible online at http://journals.ums.ac.id, Permalink/DOI: 10.23917/jep.v19i1.5505

Jurnal Ekonomi Pembangunan: Kajian Masalah Ekonomi dan Pembangunan, 19 (1), 2018, 36-49

Table 10. Common support of covariate in the matching process

\begin{tabular}{lccc}
\hline \multicolumn{1}{c}{ Type of treatment } & Covariate used & Covariate removed & Total \\
\hline Do not access KKP-E & 83 & 0 & 83 \\
Access KKP-E & 175 & 0 & 175 \\
Number of Covariate & 258 & 0 & 258 \\
\hline
\end{tabular}

Table 11. Measuring the performance of KKP-E using teffectspsmatch

\begin{tabular}{|c|c|c|c|c|c|c|}
\hline $\begin{array}{c}\text { Name of Performance } \\
\text { Variable }\end{array}$ & Sample & Coefficient & $\begin{array}{l}\text { Standard } \\
\text { Error }\end{array}$ & $\mathbf{z}$ & $\mathbf{p}>|\mathbf{z}|$ & $\%$ \\
\hline Fertilizer use & ATET & 62.62 & 44.53 & 1.41 & 0.160 & 7.43 \\
\hline Pesticide use & ATET & 1.56 & 0.44 & 3.48 & 0.001 & 15.01 \\
\hline Labor outside farm household use & ATET & 76.96 & 70.27 & 1.10 & 0.273 & 14.88 \\
\hline Productivity & ATET & 1.73 & 2.92 & 0.59 & 0.553 & 3.33 \\
\hline Farm profit & ATET & 0.93 & 0.60 & 1.55 & 0.122 & 10.31 \\
\hline
\end{tabular}

Table 9 shows the difference between the performance of treatment group and control group through by psmatch 2 after balancing test.

In the matching process of propensity score, all covariates were found to be matched or the total of common support was 258 units which consisted of 175 units of the treatment group and 83 unit of the control group. The common support can be seen in Table 10. Therefore, there was no observation removed during the matching process.

Measuring the impact using teffectspsmatch. In addition, to apply psmatch2, there is another syntax that can be applied to measure farm performance namely teffectspsmatch in Stata 13 program. The basic difference between psmatch 2 and teffectspsmatch is that the bias is still present when using psmatch2, while the bias is removed when using teffectspsmatch. The default for teffectspsmatch is PSM with the neighbor model (1). For the further analysis, the teffectspsmatch will be considered.

Table 11 presents the impact of KKP-E on-farm performance by using the syntax of teffectspsmatch. When Table 9 and Table 11 are compared, the difference value between ATT in table 9 will be identical to the coefficient of ATET in table 11 for all outcome variables measured. It showed that the use of different syntaxes to measure KKP-E performance, in fact, resulted in the identical outcome. Hence, it can be said that the measurement result of KKP-E performance is valid.

The use of fertilizer by farm business that accessed KKP-E was higher than a farm that did not access KKP-E. Before matching process for propensity score (unmatched) was performed, the difference of average fertilizer use between respondents that accessed KKP-E and respondents that did not access KKP-E was 34.58 kilograms. After the matching of propensity score (ATET), the difference of average fertilizer use was 62.62 kilograms. Therefore, it is said that KKP-E created a higher impact of average fertilizer use of 62.62 kilograms per hectare $(7.43$ percent) compared with a farm that did not access KKP-E.

Similar to fertilizer, pesticide use in the farm that accessed KKP-E was higher than a farm that did not access KKP-E. Before propensity score (unmatched) matching was performed, the difference of average pesticide use between respondents that accessed KKP-E and respondents that did not access KKP-E was 1.60 unit of measurement. After propensity 
score (ATET) matching, the difference of average pesticide use was 1.56 unit of measurement. Thus, it can be said that KKP-E resulted in the higher impact of average pesticide use of 1.56 unit of measurement per hectare (15.01 percent) compared with a farm that did not access KKP-E.

Similar to fertilizer and pesticide, labor is a production factor of the farm. Until certain level, the use of labor will accelerate the production process and increase farm productivity. Before the matching of propensity score (unmatched) was done, the difference of average use of labor outside farm household between respondents that accessed KKP-E and respondents that did not access KKP-E was 65.58 working hours. After the matching of propensity score (ATET) was conducted, the difference of the use of labor outside farm household was 76.97 working hours. Therefore, it is said that KKP-E created an impact on higher in average use of labor outside farm household of 76.97 working hours per hectare (14.88 percent) compared with a farm that did not access KKP-E. Chemin (2008) who used survey data in Bangladesh through PSM said that access to microcredit had a positive impact on household expenditure, labor use, and participation in school.

The productivity of farm that accessed KKP-E was higher than a farm that did not access KKP-E. Before the matching of propensity score (unmatched) was done, the difference of average rice productivity between respondents that accessed KKP-E and respondents that did not access KKP-E was 7.73 quintals per hectare. After propensity score (ATET) matching was performed, the difference of average rice productivity was 1.73 quintal per hectare. Hence, it is said that KKP-E provided the impact of increasing average productivity of 1.73 quintals per hectare (3.33 percent) compared to a farm that did not access KKP-E. A different result was reported by Ali and Deininger (2012) in the rural area of Ethiopia, in which the access to credit was able to increase the productivity by 11.4 percent.
Profit of farm that accessed KKP-E was higher than the profit farm that did not access KKP-E. Before propensity score (unmatched) matching was done, the difference of average farm profit between respondents that accessed KKP-E and respondents that did not access KKP-E was Rp1.64 million. After propensity score (ATET) matching, the difference of average farm profit was Rp0.93 million. Thus, it is found that KKP-E generated the impact of the increasing average farm profit of Rp0.93 million (10.31 percent) compared to a farm that did not access KKP-E. This finding is, in fact, higher than the result of research conducted by Wadud (2013) in Bangladesh who found that the increase was only 9.46 percent. Moreover, Ibrahim and Bauer (2013), Crepon et al. (2011), Chowdhury (2009) and Farida et al. (2016) mentioned that microcredit has a positive and significant impact on the increasing income and welfare.

\section{Conclusions}

So far, accessibility of KKP-E in research location was able to increase fertilizer use of 7.43 percent, pesticide use of 15.01 percent, labor outside farm household use of 14.88 percent, productivity of 3.33 percent, and farm profit of 10.31 percent. As mentioned by Aghion and Murdoch (2005), additional capital in smallscale business will result in higher outcome compared to large-scale business. Therefore, the Government policy to provide a subsidy of credit interest to farm at small-scale business is already appropriate, and in accordance to the direction of policy subsidy in the state budget (APBN) that subsidy should be given selectively only to the society in need.

Since 2016 the KKP-E was changing to KUR (Business People Credit) Agricultural Sector. There is no significant difference between KKP-E and KUR for Agricultural Sector. Scheme of credit, by any terms (KKP-E or KUR of agricultural sector), along with the Government interest subsidy is proved to increase the production input 
use, to increase production, productivity, and farm profit. This type of policy should be remained applied in the future and stopped when society no longer needs a subsidy. All respondents (100 percent) that accessed KKP-E said that they want interest subsidy to be continued in the future.

\section{Acknowledgment}

The authors would like to thank the Indonesia Endowment Fund (Lembaga Pengelola Dana Dana Pendidikan, LPDP) who have supported in this research. Acknowledgments are also conveyed to the Government of Kendal Regency who has given permission to conduct research and members of selected farmer groups in Kendal Regency who have participated in filling questionnaires, sharing experiences and exchanging ideas in their farming efforts so that authors can obtain data, information, and valuable experience in the completion of this research. Thank you also to the colleagues of the Directorate of Investment Management System for the knowledge sharing and data which is very useful for this research. Finally, thank you was conveyed to the Editorial Board and Reviewers Partner of Jurnal Ekonomi Pembangunan.

\section{References}

Aghion, B.A.D., Murdoch, J. (2005). The Economics of Microfinance. The MIT Press Cambridge, Massachusetts, London

Ali, D.A., Deininger, K. (2012). Causes and Implications of Credit Rationing in Rural Ethiopia The Importance of Spatial Variation. Policy Research Working Paper 6069.The World Bank Development Research Group.

Cerulli, G. (2015). Econometric Evaluation of Socio-Economic Programs Theory and Applications. Advanced Studies in Theoretical and Applied Econometrics Volume 49. Springer

Chauke, P.K., Anim, F.D.K. (2013). Predicting Access to Credit by Smallholder Irrigation Farmers: A Logistic Regression Approach.
Journal Hum Ecol, 42 (3): 195-202

Chemin M. 2008. The Benefits and Costs of Microfinance: Evidence from Bangladesh. Journal of Development Studies 44 (4), pp. 463-484.

Chowdhury, A. (2009). Microfinance as a Poverty Reduction Tool: A Critical Assessment. DESA Working Paper No. 89

Crepon, B.F., Devoto, Duflo, E., Pariente, W. (2011). Impact of Microcredit in Rural Areas of Morocco: Evidence from Randomizes Evaluation [Working Paper].

Dahri.(2015). Analisis Aksessibilitas, Dampak Ekonomi dan Tingkat Pengembalian Kredit Program KKP-E pada Peternakan Sapi di Jawa Tengah. Disertasi. Sekolah Pascasarjanan Institut Pertanian Bogor.

Dewi, I.S., Dwi R., Netti T. (2015). Roles of Food Security and Energy Credit in Increasing Rice Production and Profits in Kampar Regency, Riau Province. Jurnal Dinamika Pertanian Volume XXX Nomor: 2 (163-170).

Diagne A, Zeller M. 2001. Access to Credit and its Impact on Welfare in Malawi. Research Report No. 166. Washington DC. International Foor Policy Research Institute.

Farida F., Siregar H., Nuryartono N, Intan K.P.E, (2016). An Impact Estimator Using Propensity Score Matching: People's Business Credit Program to Micro-Entrepreneurs in Indonesia. Journal of Iran Economic Review. Vol.20, No.4

Han L. 2008. Bricks Vs Clicks: Entrepreneurial Online Banking Behaviour and Relationship Banking. International Journal of Entrepreneurial Behaviors \& Research, 14 (1): $17-60$.

Ibrahim, A.L.H., Bauer, S. (2013). Access to Microcredit and its Impact on Farm Profit Among Rural Farmers in Dryland of Sudan. Global Advanced Research Journal of 
Avalaible online at http://journals.ums.ac.id, Permalink/DOI: 10.23917/jep.v19i1.5505

Jurnal Ekonomi Pembangunan: Kajian Masalah Ekonomi dan Pembangunan, 19 (1), 2018, 36-49

Agricultural Science.Vol. 2 No. 3, pp: 88-102.

Messah, O.B., Wangai, P.N. (2011). Factors that Influence the Demand for Credit for Credit Among Small-Scale Investors: a case study of Meru Central District, Kenya. Research Journal of Finance and Accounting Vol 2, No 2.

Nkuah JK, Tanyeh PA, Gaeten K. 2013. Financing Small and Medium Enterprises (SMES) in Ghana : Challenges and Determinants in Accessing Bank Credit. International Journal of Research in Social Science. Vol.2 No.3.

Ololade, R.A., Olagunju, F.I. (2013). Determinants of Access to Credit among Rural Farmers in Oyo States, Nigeria.Global Journal of Science Frontier Research Agriculture and Veterinary Science. 2013. Vol 13. Issues 2 version 1.0

Pandula, G. (2011). An Empirical Investigation of Small and Medium Enterprise's Access to Bank Finance, ASBBS Annual Conference
Proceedings, 18 (2).

Septya, F. (2013).Peranan PUAP dan Raskin dalam Perilaku Ekonomi dan Ketahanan Pangan Rumah Tangga Petani (Kasus di KecamatanSadang, KabupatenKebumen) [Tesis]. Bogor (ID) :Institut Pertanian Bogor.

Vitor, D.A, Abankwah, V. (2012). Substitutes or Compliment: Formal and Informal Credit Demand by Maize farmers in Ashanti and Brong Ahafo Regions of Ghana. The Journal of Agricultural Science. Vol 7 (1)

Wadud, M.A. (2013). Impact of Microcredit on Agricultural Farm Performance and Food Security in Bangladesh.Working Paper 14.Institute of Inclusive Finance and Development.

Wati D.R., Nuryartono N., Anggraeni L. (2014). Akses dan Dampak Kredit Mikro Terhadap Produksi dan Pendapatan Usahatani Padi Organik di Kabupaten Bogor. Jurnal Ekonomi dan Kebijakan Pembangunan. Vol.3 No.2. 